\title{
Diallel Analysis of the Combining Ability of Common Bean (Phaseolus vulgaris L.) Cultivars
}

\author{
Marco Antônio Aparecido Barelli ${ }^{1}$, Maria Celeste Gonçalves-Vidigal ${ }^{1 *}$, Antonio Teixeira \\ do Amaral Júnior ${ }^{2}$, Pedro Soares Vidigal Filho ${ }^{1}$ and Carlos Alberto Scapim ${ }^{1}$ \\ ${ }^{1}$ Departamento de Agronomia, Universidade Estadual de Maringá, Av. Colombo, 5790, 87020-900, Maringá- \\ Paraná, Brazil; ${ }^{2}$ Laboratório de Melhoramento Genético Vegetal, Centro de Ciências e Tecnologias Agropecuárias, \\ Universidade Estadual do Norte Fluminense, Av. Alberto Lamego, 2000, Horto, 28015-620, Campos dos \\ Goytacazes-Rio de Janeiro, Brazil.
}

\begin{abstract}
Six common bean cultivars (LPSPI 93-17, LPSPI 93-19, FT-Nobre, Aporé, Rudá and Campeão-1) and their 15 diallel hybrids were evaluated for four agronomic characteristics using Griffing's methodology (1956). The analysis indicated the predominance of non-additive gene effects for days to germination and plant height. The mean number of days to flowering and mean height of the first pod insertion were predominantly controlled by genes showing additive effects. The results showed that LPSI 93-19 and Aporé were indicated for intra-population breeding, while the combinations LPSPI 93-17 x FT-Nobre, LPSPI 93-17 x Aporé, LPSPI 93-17 x Rudá, LPSPI 93-19 x Campeão-1, FT-Nobre $x$ Aporé and Rudá $x$ Campeão- 1 were indicated for interpopulational breeding. Plants with reduced height, greater height of first pod insertion, fewer number of days to flowering and to emergence can be obtained from the segregant population of the crosses LPSPI 93-17 x FT-Nobre and LPSPI 93-19 x Rudá.
\end{abstract}

Key words: Common bean, Phaseolus vulgaris, diallel analysis, plant breeding

\section{INTRODUCTION}

The genetic variability in the Brazilian germplasm is very large due to the environmental conditions of cultivation. The innumerable plant introductions made and was maintained by the diversity of consumer and farmer preferences. This large variability is essential for the success of breeding programs for practically all the important economically characteristics (Ramalho et al. 1993).

Greater bean productivity could be obtained through hybridization of superior cultivars. The diallel cross could be a viable alternative because it allows a wide recombination of the genomes with greater chances of generating superior cultivars in segregant generations (Ayele, 1994; Cruz and Regazzi, 1994). Obtaining cultivars with a better productive performance should be one of the primary goals of bean breeding programs. A feasible breeding alternative is to broaden the genetic base for selection using hybridization since the common bean is an autogamous species and the variability within population is generally inexpressive (Costa and Zimmermann, 1989).

Ramalho et al. (1993) pointed out that, although multiple crosses offer opportunities for the recombination of genes present in the different parents, the proportional increase in the number of intercross cycles as the new parents take part in the process becomes an inconvenience. Furthermore, to maintain the favorable alleles from all the parents, the size of the $F_{1}$ population has to increase according to the increase in the number of cycles, which implies greater effort in carrying out manual crosses. The use of diallel analysis procedures to widen the genetic base of the Phaseolus vulgaris species has received a lot of emphasis recently from bean breeders. Santos and Vencovsky (1985) and Schaff et al. (1987) stated that diallel analysis could provide information for choosing the most suitable selection method because it provides the breeder with early knowledge of the important genetic parameters involved.

\footnotetext{
* Author for correspondence
} 
Obtaining short cycle cultivars allows a greater use of the cultivated area, with an increase in the number of crop cycles per year. Diallel studies with eight common bean cultivars carried out by Santos and Vencovsky (1985), based on the methods developed by Jinks and Hayman (1953), Hayman $(1954 ; 1958)$ and Jones (1965), identified predominant additive genetic action compared to dominance for the characteristic number of days to flowering. It was also found that this characteristic was little influenced by the environment, which could make selection of cultivars with potential for cycle reduction more reliable in segregating populations.

The present study was carried out using a diallel cross system among six common bean cultivars to assess the general and specific combining abilities and discriminate the superior parents and hybrid combinations, as an initial step in developing a breeding program for the species to increase productivity in the Northeast of Paraná state.

\section{MATERIALS AND METHODS}

The common bean cultivars LPSPI 93-17, LPSPI 93-19, FT-Nobre, Aporé, Rudá, and Campeão-1, were chosen because of their divergent morphological and agronomic characteristics, and used as parents in a complete diallel without reciprocals.

The method proposed by Vieira (1967), which consisted of mechanical emasculation of the female parent using tweezers/pincers on flower buds one day before flowering followed by crossed pollination using ripe pollen from open flowers of the male parents, was used to perform the crosses.

Treatment and experimental design: The populations consisting of six parents and $15 \mathrm{~F}_{1}$, totaling 21 treatments were assessed in the greenhouse at the Nucleus for Research Applied to Agriculture (Nupagri), at the Department of Agronomy, UEM, Maringá, PR in 1997. The experimental design was a randomized complete block with ten replications. Four seeds were sown in $5 \mathrm{dm}^{3}$ pot containing substrate. They were thinned seven days after emergence, and two plants were left in each pot. Each pot with two plants made up a experimental unit.

The following characteristics were assessed: a) mean number of days to emergence (EMERG): assessed as the average of the number of days from sowing to the rising of the cotyledon at soil level of all plants in each treatment;

b) number of days to flowering (FLORESC): obtained by counting the number of days, from sowing to the complete opening of the first flower, of each plant in each treatment;

C) mean height of the insertion of the first pod (ALTINS): expressed in $\mathrm{cm}$, as the ratio between the measurement from the soil to the insertion of the first pod and the respective number of plants in each treatment;

d) mean final plant height (ALTP): expressed in $\mathrm{cm}$, as the ratio between the measurement from the soil to the highest point of the plant and the respective number of plants in each treatment.

An analysis of variance using a randomized complete block design for the data of each characteristic was carried out. The value of each observation provided by the following statistical model, taking cultivar as fixed effects was used:

$$
Y_{i j}=m+g_{i}+b_{j}+E_{i j},
$$

Where:

$\mathrm{Y}_{\mathrm{ij}}=$ observation of $\mathrm{i}^{\text {th }}$ treatment in the $\mathrm{j}^{\text {th }}$ block (i $=1,2, \ldots, g=6 ; j=1,2, \ldots, b=10)$;

$\mathrm{m}=$ general mean;

$g_{i}=$ effect of the $i^{\text {th }}$ cultivar;

$b_{j}=$ effect of the $j^{\text {th }}$ block;

$\mathrm{E}_{\mathrm{ij}}=$ experimental error.

Griffing's diallel analysis (1956): The partitioning of the sum of squares of the treatment means in sum of the squares for general and specific combining ability was carried out according to Griffing's (1956), Method 2 (parents and $F_{1}$ hybrids) Model 1 (fixed effects). This model was adopted because the diallel parents could not be considered a sample of the common bean species. They formed a population with particular genetic properties (Gardner and Ebehart, 1966; Sokol and Baker, 1977) and all the possible references and conclusions led by the present analyses only applied to this population.

\section{RESULTS AND DISCUSSION}

The analysis of variance showed significant differences at the $1 \%$ level of probability for the evaluated characteristics. Table 1 shows the 
partitioning of the sum of the squares attributed to the genotype effects as well as the means of the squares of the effects for the four characteristics. The values of the mean squares for general combining ability (GCA) for all the characteristics evaluated were highly significant at the $1 \%$ level of probability, by the $\mathrm{F}$ test. The characteristics
EMERG, FLORESC and ALTP were also significant at the $1 \%$ probability level for the specific combining ability (SCA) while there was no significant difference for ALTINS by the test carried out.

Table 1. Mean squares from diallel analysis of $F_{1}$ generation and parents

\begin{tabular}{|c|c|c|c|c|c|}
\hline \multirow[b]{2}{*}{ SV } & \multirow[b]{2}{*}{ DF } & \multicolumn{2}{|r|}{ Mean } & \multicolumn{2}{|l|}{ Squares $^{1 /}$} \\
\hline & & EMERG & FLORESC & ALTINS & ALTP \\
\hline Treatments & 20 & $5.6490 * *$ & $13.3062 * *$ & $33.3108 * *$ & $2668.1413 * *$ \\
\hline GCA & 5 & $13.7832 * *$ & $41.0361 * *$ & $103.9280 * *$ & $3445.4897 * *$ \\
\hline SCA & 15 & $2.9376 * *$ & $4.0629 * *$ & $9.7717^{\mathrm{ns}}$ & $2409.0251 * *$ \\
\hline Error & 180 & 0.4749 & 1.2676 & 8.2676 & 839.2109 \\
\hline \multicolumn{6}{|c|}{ Mean square of effects } \\
\hline GCA & & 0.1663 & 0.4971 & 1.1957 & 32.5784 \\
\hline SCA & & 0.2462 & 0.2795 & 0.1504 & 156.9814 \\
\hline Error & & 0.4749 & 1.2676 & 8.2676 & 839.2109 \\
\hline
\end{tabular}

${ }^{1 /}$ EMERG = mean number of days to emergence; FLORESC = number of days to flowering; ALTINS = height of the first pod insertion; ALTP = mean final plant height; $\mathrm{DF}=$ degree freedom; $\mathrm{SV}=$ source of variation; $\mathrm{GCA}=$ general combining ability; SCA = specific combining ability

$* *$ singnificant at $1 \%$ level.

ns $=$ no significant.

The significant GCA and SCA differences observed among the cultivars indicated that additive and non-additive genetic effects were involved in the control of these characteristics. Therefore, new cultivars could be obtained from these parents. The exception was new hybrid combinations (non-significant SCA) for the ALTINS characteristic.

The mean squares for GCA were greater than those corresponding to SCA for the assessed characteristics. For EMERG and ALTP, a predominance of the non-additive genetic effects, expressed by the comparison among the SCA and GCA, 0.2462 and $0.1663 ; 156.9814$ and 32.5784 , respectively, was observed. Therefore, the interpopulational breeding strategy using the heterosis effects could give superior gains to these characteristics comparatively to the intrapopulational breeding strategy (Table 1).
Cruz and Regazzi (1994) pointed out that the inferiority of the quadratic component associated with GCA has been found in diallels where the parents had been previously selected for the characteristic under study. This explains the occurrence of the greater influence of the nonadditive genetic effects comparatively to the additive effects for the EMERG and ALTP characteristics in this study. The genetic additive effects were greater than the non-additive effects for the characteristics FLORESC and ALTINS, indicating that the best option to adopt was the respective use of the cultivars in intrapopulational breeding programs.

General Combining Ability (GCA): Table 2 shows the estimates of the effects of GCA $\left(g_{i}\right)$ of the parents for the four assessed characteristics and the standard deviation (SD) among any two parents.

Table 2. General combining ability (GCA) effects of six cultivars in common bean 


\begin{tabular}{lcccc}
\hline \multicolumn{1}{c}{ Cultivars } & EMERG & FLORESC & ALTINS & ALTP \\
\hline 1. LPSPI - 93-17 & -0.2708 & 0.5500 & 0.5020 & 7.7166 \\
2. LPSPI - 93-19 & -0.1458 & -0.8625 & 1.7583 & -7.2708 \\
3. FT-Nobre & -0.5958 & -0.3250 & -0.5041 & -4.9833 \\
4. Aporé & 0.1291 & -0.7000 & 0.5270 & 8.2416 \\
5. Rudá & 0.3916 & 0.5499 & -1.0604 & -0.5583 \\
6. Campeão-1 & 0.4916 & 0.7874 & -1.2229 & -3.1458 \\
\hline SD $\left(\hat{g}_{\mathrm{i}}-\hat{g}_{\mathrm{i}}\right)$ & & & & \\
\hline
\end{tabular}

${ }^{1 /}$ EMERG = mean nunber of days to emergence; FLORESC = number of days to flowering; ALTINS = height of the first pod insertion; ALTP = mean final plant height; $\mathrm{SD}=$ standard deviation.

The were FT-Nobre, LPSPI 93-17 and LPSPI 9319 cultivars, in this order, the most indicated for inclusion in breeding programs for increases in seed vigor for greater speed in seedling emergence. They showed $g_{i}$ values of -0.5958 , 0.2708 , and -0.1458 , respectively, for emergence. The results of these procedures would rapid soil protection and more use of solar radiation. On the other hand, the cultivars Aporé, Rudá and Campeão-1, especially the last one, tended to contribute negatively to plant vigor when in hybrid combinations.

Regarding the FLORESC characteristic (Table 2), reduction in the crop cycle could be obtained by using the LPSPI 93-19, FT-Nobre and Aporé cultivars in breeding programs since they had negative $g_{i}$ estimates, respectively, -0.8625 , -0.3250 and -0.7000 . When these two characteristics (EMERG and FLORESC) are analyzed together, the LPSPI 93-19 and FT-Nobre cultivars should receive attention from breeders working for the Northwest region of Paraná due to their potential for reduction in the emergence and flowering periods when in hybrid combinations. This possibility would allow early cultivars to be obtained, resulting in a better use of the cultivated area by farmers, who could thus get a greater number of harvests during a single year. Regarding GCA effects, high $g_{i}$ estimates in absolute values are normally found in cultivars whose frequencies of favorable alleles are consistently higher or lower than the mean frequency of favorable alleles in all the tested cultivars (Vencovsky, 1970).

The LPSPI 93-17, LPSPI 93-19 and Aporé cultivars had positive $g_{i}$ values for height of insertion of the first pod, expressed respectively by $0.5020,1.7583$ and 0.5270 (Table 2), showing that they should be used in programs for increasing this characteristic. Adequate first pod insertion was essential for mechanical harvesting and was also important to avoid pod contact with the soil and the consequent product degradation of the cultivars with indeterminate and prostrate growth habit (type III), only LPSPI 93-17 and Aporé tended to provide a good genetic contribution for greater height. They had positive $g_{i i}$ effects and a high ALTP size. It is important to point out in this study that although the Rudá cultivar had a prostrate and indeterminate growth habit, it is classified between types II and III which may have contributed to its negative $g_{i}$ value for ALTP. This value, however, was relatively low in size (0.5583 ), indicating that its influence for plant size reduction in intercrossing programs may be small. The results obtained from $g_{i}$, the LPSPI 93-19 and Aporé cultivars are preferred for inclusion in breeding programs for increasing earliness and increasing the height of the insertion of the first pod in cultivars under selection. Such programs could include intra or interpopulational methods to obtain promising hybrids or superior segregant cultivars in advanced generations.

Specific Combining Ability (SCA): The results of $s_{i j}$ (Table 3) for the EMERG characteristic showed that the negative effects which were interesting because of the reduction of the seed emergence period were present in the LPSPI 93-17 x FT-Nobre (-0.6571), Aporé x Rudá (-0.1446) and LPSPI 93-19 x Rudá (-0.0696) combinations.

The FLORESC characteristic, the promising combinations were LPSPI 93-17 x LPSPI 93-19, LPSPI 93-17 x FT-Nobre, FT-Nobre x Aporé, LPSPI 93-19 x FT-Nobre, LPSPI 93-17 x Campeão-1, LPSPI 93-17 x Rudá, LPSPI 93-19 x Rudá and LPSPI 93-17 x Aporé, with $s_{i j}$ values of 
$-1.0446,-0.5821,-0.5321,-0.4696,-0.1946, \quad-$ $0.1571,-0.1446$ and -0.1071 , respectively (Table 3). According to Griffing (1956), the best combination should be that with greater $s_{i j}$ whose parents have high GCA. Using this premise to analyze the EMERG and FLORESC characteristics, it may be inferred that the best hybrid combinations are LPSPI 93-17 x LPSPI 9319, LPSPI 93-17 x FT-Nobre and LPSPI 93-19 x Rudá.

Table 3. Estimates of specific combining ability four characteristics of the $F_{1}$ population

\begin{tabular}{|c|c|c|c|c|}
\hline Effects $^{1 /}$ & & Characteristic & $2 / 1$ & \\
\hline$\left(s_{\mathrm{ii}}\right.$ e $\left.\mathrm{s}_{\mathrm{ij}}\right)$ & EMERG & FLORESC & ALTINS & ALTP \\
\hline $1 \times 1$ & -0.6821 & 1.0428 & -0.7374 & -6.9571 \\
\hline $1 \times 2$ & 0.4928 & -1.0446 & 1.1562 & 2.8303 \\
\hline $1 \times 3$ & -0.6571 & -0.5821 & 0.2187 & -8.3571 \\
\hline $1 \times 4$ & 0.5178 & -0.1071 & 0.1375 & 18.1178 \\
\hline $1 \times 5$ & 0.4553 & -0.1571 & 0.4250 & 5.5178 \\
\hline $1 \times 6$ & 0.5553 & -0.1946 & -0.4624 & -4.1946 \\
\hline $2 \times 2$ & -0.1321 & 0.1678 & -0.2499 & -11.1821 \\
\hline $2 \times 3$ & 0.5821 & -0.4696 & -0.6374 & -14.0696 \\
\hline $2 \times 4$ & 0.1928 & 0.9053 & -1.3687 & 34.0053 \\
\hline $2 \times 5$ & -0.0696 & -0.1446 & 0.4187 & -7.8946 \\
\hline $2 \times 6$ & 0.2303 & 0.4178 & 0.9312 & 7.4928 \\
\hline $3 \times 3$ & -0.0321 & 0.0928 & -0.1249 & -1.9571 \\
\hline $3 \times 4$ & 0.1428 & -0.5321 & 1.1437 & 16.1178 \\
\hline $3 \times 5$ & 0.4803 & 0.7178 & 0.0812 & 11.2178 \\
\hline $3 \times 6$ & 0.6803 & 0.6803 & -0.5562 & -0.9946 \\
\hline $4 \times 4$ & -0.4821 & -0.3571 & 1.3625 & -30.7071 \\
\hline $4 \times 5$ & -0.1446 & 0.0928 & -1.5999 & -6.0071 \\
\hline $4 \times 6$ & 0.2553 & 0.3553 & -1.0374 & -0.8196 \\
\hline $5 \times 5$ & -0.4071 & -0.3571 & -0.3125 & -5.9071 \\
\hline $5 \times 6$ & 0.0928 & 0.2053 & 1.3000 & 8.9803 \\
\hline $6 \times 6$ & -0.9071 & -0.7321 & -0.0874 & -5.2321 \\
\hline $\mathrm{SD}\left(\mathrm{s}_{\mathrm{ii}}-\mathrm{S}_{\mathrm{ij}}\right)$ & 0.2179 & 0.3560 & 0.9092 & 9.1608 \\
\hline $\mathrm{SD}\left(\mathrm{s}_{\mathrm{ij}}-\mathrm{s}_{\mathrm{ik}}\right)$ & 0.2883 & 0.4709 & 1.2028 & 12.1186 \\
\hline $\mathrm{SD}\left(\mathrm{s}_{\mathrm{ij}}-\mathrm{S}_{\mathrm{kl}}\right)$ & 0.2669 & 0.4360 & 1.1136 & 11.2196 \\
\hline
\end{tabular}

1/ (1) LPSPI 93-17, (2) LPSPI 93-19, (3) FT-Nobre, (4) Aporé, (5) Rudá and (6) Campeão-1.

${ }^{2 /}$ EMERG = mean nunber of days to emergence; FLORESC = number of days to flowering; ALTINS = height of the first pod insertion; ALTP = mean final plant height; $\mathrm{SD}=$ standard deviation.

The hybrids with the greatest positive $s_{i j}$ effects for the ALTINS characteristic were Rudá $\mathrm{x}$ Campeão-1, LPSPI 93-17 x LPSPI 93-19, FTNobre x Aporé and LPSPI 93-19 x Campeão-1, with values $1.3000,1.1562,1.1437$ and 0.9312 , respectively (Table 3). This showed that the desirable complementary genetic effect of the parents LPSPI 93-17, LPSPI 93-19 and Aporé (Table 2) was expressed in the mentioned combinations. On the other hand, the good performance of the Rudá $x$ Campeão-1 combination, which was not expected based on the parents negative $g_{i}$ values (Table 2), indicated that the hybrid behavior was better than supposed.

The analyses of the ALTP characteristic (Table 3) indicated that when plant size reduction is required, the LPSPI 93-19 x FT-Nobre, LPSPI 9317 x FT-Nobre, LPSPI 93-19 x Rudá and Aporé x Rudá combinations should be considered. They have, respectively, $s_{i j}$ values of $-14.0696,-8.3571$, -7.8946 and -6.0071 . The greatest heights of insertion of the first pod, earliness and reduced size coupled with vigorous plant were essential to avoid pod contact with the soil, preserve the quality of the seeds and facilitate mechanical harvesting. The use of the LPSPI 93-17 x FTNobre and LPSPI 93-19 x Rudá hybrids are recommended in the choice of superior genotypes. Their derived segregant populations have a high potential to generate superior lines.

The results showed that: a) the non-additive genetic effects predominated in the expression of 
the number of days to emergence and mean plant height; b) the additive genetic effects were superior for mean number of days to flowering, mean height and insertion of the first pod; c) the LPSPI 93-19 and Aporé cultivars have been indicated for intrapopulational breeding programs; and d) plants of reduced size, greater height of insertion of the first pod, lower number of days to flowering and to emergence could be obtained from the segregant populations of the crosses LPSPI 93-17 x FT-Nobre and LPSPI 93-19 X Rudá.

\section{RESUMO}

Seis cultivares de feijoeiro (Phaseolus vulgaris L.) LPSPI 93-17, LPSPI 93-19, FT-Nobre, Aporé, Rudá e Campeão-1 e seus 15 híbridos dialélicos possíveis, foram avaliados quanto a quatro características morfoagronômicas, utilizando-se a metodologia de Griffing (1956). A análise dialélica indicou a predominância de efeitos gênicos não-aditivos para as características número médio de dias para a germinação e altura média das plantas. As características número médio de dias para o florescimento, altura média da inserção da primeira vagem, ao contrário, acusaram superioridade dos efeitos gênicos aditivos. Pelas estimativas das capacidades combinatórias, LPSPI 93-19 e Aporé são os indicados para melhoramento intrapopulacional, enquanto para intercruzamentos, a indicação recai sobre as combinações LPSPI 93-17 x FT-Nobre, LPSPI 93-17 x Aporé, LPSPI 93-17 x Rudá, LPSPI 93-19 x Campeão-1, FT-Nobre x Aporé e Rudá x Campeão-1. Plantas com porte reduzido, maior altura de inserção da primeira vagem, menor número de dias para o florescimento e para emergência poderão ser obtidas a partir das populações segregantes dos cruzamentos LPSPI 93-17 x FT-Nobre e LPSPI 93-19 x Rudá.
Ayele, M. (1994), Diallel analyses for yield and yield components in haricot bean, Phaseolus vulgaris. Ann. Rep. Bean Improv. Coop. 37: 159-160

Costa, J. G.da \& Zimmermann, M. J. O. (1989), Melhoramento genético do feijoeiro. In- Cultura do feijoeiro, eds. M.J.O Zimmermann; M. Rocha \& T. Yamada. ABPPF, Potafos, Piracicaba. 229-248

Cruz, C. D. \& Regazzi, A. J. (1994), Modelos biométricos aplicados ao melhoramento genético. UFV, Viçosa. 394

Gardner, C. O.\& Ebehart, S. A. (1966), Analysis and interpretation of the variety cross diallel and related populations. Biometrics. 22: 439-452

Griffing, B. (1956), Concept of general and specific combining ability in relation to diallel crossing systems. Austr. J. Biol. Sci. 9: 463-493

Hayman, B. I. (1954), The theory and analysis of diallel crosses. Genetics. 39: 789-809

Hayman, B. I. (1958), The theory and analysis of diallel crosses II. Genetics. 43: 63-85

Jinks, J. L. \& Hayman, B. I. (1953), The analysis of diallel crosses. Maize Genet. Coop. Newls. 27: 48-54

Jones, R. M. (1965), Analysis of variance of the half diallel table. Heredity, 20: 177-121

Ramalho, M. A. P.; Santos, J. B. dos \& Zimmermann, M. J. de O. (1993), Genética quantitativa em plantas autógamas: aplicação ao melhoramento do feijoeiro. UFG, Goiânia. 271

Santos, J. B. dos \& Vencovsky, R. (1985), Controle genético do início do florescimento em feijoeiro. Pesq. Agrop. Bras. 20: 841-845

Schaff, D. A.; Milliken, G. A. \& Clayberg, C. D. (1987), Computational procedure for a weighted diallel analysis. Theor. Appl. Genet. 74: 538-541

Sokol, M. J. \& Baker, R. J. (1977), Evaluation of the assumptions required for the genetic interpretation of diallel experiments in selfpollination crops. Can. J. Plant Sci. 57: 1185-1191

Vencovsky, R. (1970), Alguns aspectos teóricos e aplicados relativos a cruzamentos dialélicos de variedades. Doctoral Thesis, ESALQ/USP, Piracicaba, SP.

Vieira, C. (1967), O feijoeiro comum: cultura, doenças e melhoramento. Imprensa Universitária, Viçosa. 220

Received: June 28, 1999

Revised: July 06, 1999;

Accepted: December 13, 1999

\section{REFERENCES}

